\title{
Pemahaman Siswa tentang Globalisasi dan Sikap Cinta Tanah Air dengan Pelestarian Budaya Bangsa
}

\author{
Nur'Aini $^{1}$, Mohamad Abduh $^{2} *$, Suidat $^{2}$ \\ ${ }^{1}$ SMK Arrahman Depok, Indonesia \\ ${ }^{2}$ STKIP Arrahmaniyah, Indonesia
}

\begin{abstract}
Abstrak-Penelitian ini bertujuan untuk memperoleh data empiris mengenai hubungan pemahaman siswa tentang globalisasi dan sikap cinta tanah air dengan pelestarian budaya bangsa. Penelitian ini dilaksanakan bulan Juli sampai Oktober 2020. Metode yang digunakan adalah metode deskriptif kuantitatif dengan studi koralasional. Jumlah sampel sebanyak 181 siswa yang didapat secara acak. Penelitian ini menyimpulkan; (1) Terdapat hubungan positif yang sangat signifikan antara pemahaman siswa tentang globalisasi dengan pelestarian budaya bangsa dengan koefisien korelasi $\left(r_{y 1}\right)$ sebesar $0,5450(\alpha=0,05)$. Kontribusi pemahaman tentang globalisasi sebesar $29,71 \%\left(r_{y 1}\right)$. (2) Terdapat hubungan positif yang sangat signifikan antara sikap cinta tanah air dengan pelestarian budaya bangsa dengan koefisien korelasi $\left(r_{y 2}\right)$ sebesar $6,501(\alpha=0,05)$. Kontribusi sikap cinta tanah air dengan pelestarian budaya bangsa sebesar $19,10 \%\left(r_{y 2}\right)$. Terdapat hubungan positif yang sangat signifikan antara pemahaman siswa tentang globalisasi dan sikap cinta tanah air secara bersama-sama dengan pelestarian budaya bangsa dengan koefisien korelasi $\left(r_{y 12}\right)$ sebesar $0,6117(\alpha=0,05)$. Kontribusi pemahaman siswa tentang globalisasi dan sikap cinta tanah air dengan pelestarian budaya bangsa sebesar
\end{abstract} Kata kunci: Globalisasi, Cinta Tanah Air, Budaya Bangsa. $37,42 \%\left(\mathrm{R}_{\mathrm{y} 12}\right)$.

(C)2021 JCC. All rights reserved

\section{Histori:}

Dikirim: 08 Maret 2021

Direvisi: 10 Maret 2021

Diterima: 14 Maret 2021

Online: 18 Maret 2021

(c) (i) (2) Author(s) agree that this article remains permanently open access under the terms of the Creative Commons

\section{Identitas Artikel:}

Nur'aini, N., Abduh, M., \& Suidat, S. (2021). Pemahaman Siswa tentang Globalisasi dan Sikap Cinta Tanah Air dengan Pelestarian Budaya Bangsa. Jurnal Citizenship Virtues, 1(1), 22-26.

\section{PENDAHULUAN}

Bangsa yang mau dan mampu menghargai kekayaan yang dimiliki, yang berupa keanekaragaman kebudayaan. Sikap menghargai budaya perlu dikembangkan agar kebudayaan yang terkenal tinggi nilainya itu tetap lestari, tidak terkena arus yang datang dari luar. Dengan pemahaman yang dimiliki tentang globalisasi akan melahirkan sikap menghargai budaya bangsa dan pada akhirnya akan melahirkan kepedulian siswa untuk melestarikan keragaman (Rostini, 2018). Dapat dikatakan bahwa globalisasi membawa persepektif baru tentang konsep "Dunia Tanpa Batas" (Iriansyah, 2020), yang saat ini telah menjadi realita dan berpengaruh secara signifikan terhadap perkembangan budaya yang akhirnya membawa perubahan

\footnotetext{
*Corresponding author

E-mail: mohamadabduh73@gmail.com
} 
baru. Waters (dalam Rusli, 2013) menyatakan Globalisasi adalah suatu proses sosial yang berdampak pada terbatasnya geografis, dan sosial budaya menjadi tidak utama, yang muncul adalah kesadaran individu. Ritcher (dalam Riwanto, 2016; Arjoni \& Handayani, 2017) menyatakan globalisasi merupakan jaringan kerja global yang dapat mempersatukan masyarakat yang terpisah dan terisolasi serta sangat tergantung dengan orang lain. Friedman (dalam Kartini, 2017; Arjoni \& Handayani, 2017; Rostini, 2018) juga menjelaskan bahwa globalisasi mempunyai dimensi ideology dan teknologi, yaitu kapitalisme dan pasar bebas, sedangkan dimensi teknologi adalah teknologi informasi yang telah menyatukan dunia.

Kurangnya iman dan taqwa dalam menghadapi perkembangan globalisasi dapat melunturkan sikap cinta tanah air seorang peserta didik, sehingga jika hal itu dianggap hal biasa maka budaya bangsa Indonesia yang menjadi asset berharga bagi bangsa lambat laun akan hilang. Suyadi (2013) menyatakan bahwa cinta tanah air adalah sikap dan perilaku yang tampak dengan indicator: adanya kebanggaan, kesetiaan, kepedulian dan pengehargaan pada bahasa, budaya, ekonomi, poloitik, sehingga tidak tergoda dengan tawaran bangsa lain yang merugikan bangsa sendiri. Para siswa diharapkan dalam ucapan, sikap, dan perilakunya menggambarkan karakter yang luhur (Suwarna \& Jatirahayu, 2013). Melalui pendidikan diharap dapat menumbuhkan nilai-nilai budi pekerti dan moral sehingga siswa memiliki akhlak mulia dan berbudi pekerti luhur. Hal ini akan terbentuk bila dalam proses pembelajaran guru hendaknya tidak mengutamakan nilai kognitif saat menyampaikan materi pembelajaran di kelas, namun nilai afektif dan psikomotor harus lebih diperhatikan. Proses pembelajaran yang berlangsung di kelas tidak terpusat pada guru dan harus melibatkan siswa (Pudjiastuti, 2020).

\section{METODE PENELITIAN}

Penelitian ini menggunakan jenis penelitian kuantitatif, dengan pendekatan korelasional. Pengumpulan data menggunakan instrument penelitian, analisis data bersifat kuantitatif/statistic dengan tujuan untuk menguji hipotesis yang ditetapkan (Pudjiastuti, 2019). Penelitian ini dilakukan di SMK Arrahman di Depok Wilayah Kecamatan Cipayung. Waktu penelitian ini dilakukan dari bulan Juli sampai dengan Oktober 2020. Populasi yang peneliti ambil sebanyak 329 siswa. Dalam hal ini penulis mempersempit populasi yaitu jumlah seluruh siswa sebanyak 329 siswa dengan menghitung ukuran sampel yang dilakukan dengan menggunakan teknik Slovin (dalam Sugiyono, 2008) menjadi 181 siswa. Pengumpulan data variabel pemahaman globalisasi dengan menggunakan tes, sedangkan variabel sikap cinta tanah air dengan angket sikap dan variabel pelestarian budaya bangsa dengan angket perilaku. Alat ukur yang baku adalah yang dibuat dengan tahapan pengembangan instrumen yang terstandar dan dapat diuji tingkat keakuratnnya melalui uji validitas dan reliabilitas (Pudjiastuti, 2018).

\section{HASIL DAN PEMBAHASAN}

\section{Pemahaman tentang Globalisasi dengan Pelestaraian Budaya Bangsa}

Berikut adalah hasil analisis korelasi antara Pemahaman tentang Globalisasi dan Pelestaraian Budaya Bangsa yang disajikan dalam Tabel 1. 
Nur'Aini, Abduh \& Suidat

Tabel 1. Korelasi Pemahaman Globalisasi dengan Pelestarian Budaya Bangsa

\begin{tabular}{llrr}
\hline & & Pemahaman & Pelestarian \\
\hline Pemahaman & Pearson Correlation & 1 & $.545^{* *}$ \\
& Sig. (2-tailed) & & .000 \\
& $\mathrm{~N}$ & 181 & 181 \\
\hline Pelestarian & Pearson Correlation & $.545^{* *}$ & 1 \\
& Sig. (2-tailed) & .000 & \\
& $\mathrm{~N}$ & 181 & 181 \\
\hline
\end{tabular}

**. Correlation is significant at the 0.01 level (2-tailed).

Berdasarkan Tabel 1, diperoleh $r_{\text {hitung }}=0,5450$. Hasil tersebut kemudian dikonsultasikan dengan $r_{\text {tabel }}=0,1459(\alpha=0,05$ dan $\mathrm{N}=181)$. Hasil konsultasi tersebut menunjukan bahwa $r_{\text {hitung }}=0,5450 \geq 0,1459=r_{\text {tabel, }}$ yang artinya terdapat hubungan antara pemahaman globalisasi dengan pelestarian budaya bangsa.

\section{Sikap Cinta Tanah Air dengan Pelestaraian Budaya Bangsa}

Berikut adalah hasil analisis korelasi antara sikap cinta tanah air dan pelestaraian budaya bangsa yang disajikan dalam Tabel 2 .

Tabel 2. Korelasi Sikap Cinta Tanah Air dengan Pelestarian Budaya Bangsa

\begin{tabular}{llrr}
\hline & & \multicolumn{1}{c}{ Sikap } & Pelestarian \\
\hline Sikap & Pearson Correlation & 1 & $.437^{* *}$ \\
& Sig. (2-tailed) & & .000 \\
& $\mathrm{~N}$ & 181 & 181 \\
\hline Pelestarian & Pearson Correlation & $.437^{* * *}$ & 1 \\
& Sig. (2-tailed) & .000 & \\
& $\mathrm{~N}$ & 181 & 181 \\
\hline
\end{tabular}

**. Correlation is significant at the 0.01 level (2-tailed).

Berdasarkan Tabel 2, diperoleh $r_{\text {hitung }}=0,4371$. Hasil tersebut kemudian dikonsultasikan dengan $r_{\text {tabel }}=0,1459(\alpha=0,05$ dan $\mathrm{N}=181)$. Hasil konsultasi tersebut menunjukan bahwa $r_{\text {hitung }}=0,4371 \geq 0,1459=r_{\text {tabel }}$, yang artinya terdapat hubungan antara sikap cinta tanah air dengan pelestaraian budaya bangsa.

Untuk menguji signifikansi hubungan antar variabel menggunakan Uji- $t$ yang digunakan untuk mengetahui hubungan signifikan pemahaman globalisasi $\left(\mathrm{X}_{1}\right)$ dengan pelestarian budaya bangsa $(\mathrm{Y})$ dan hubungan sikap cinta tanah air $\left(\mathrm{X}_{2}\right)$ dengan pelestarian budaya bangsa (Y). Adapun hasilnya Uji- $t$ sebagai berikut.

Tabel 3. Uji- $t$

\begin{tabular}{lccc}
\hline \multicolumn{1}{c}{ Variabel } & $t_{\text {hitung }}$ & $t_{\text {tabel }}$ & Ket \\
\hline $\begin{array}{l}\text { Pemahaman globalisasi }\left(\mathrm{X}_{1}\right) \text { dengan } \\
\text { pelestarian budaya bangsa }(\mathrm{Y})\end{array}$ & 8,6978 & 2,045 & Signifikan \\
$\begin{array}{l}\text { Sikap cinta tanah air }\left(\mathrm{X}_{2}\right) \text { dengan } \\
\text { pelestarian budaya bangsa }(\mathrm{Y})\end{array}$ & 6,501 & 2,045 & Signifikan \\
\hline
\end{tabular}

Berdasarkan Tabel 3, diketahui bahwa $t_{\text {hitung }}$ lebih dari $t_{\text {tabel, }}$, maka antar variabel memiliki hubungan yang signifikan. 


\section{Pemahaman tentang Globalisasi dan Sikap Cinta Tanah Air terhadap Pelestaraian Budaya Bangsa}

Uji hipotesis penelitian yang mengkaji hubungan signifikan antara Pemahaman tentang Globalisasi dan Sikap Cinta Tanah Air dengan Pelestarian Budaya Bangsa dilakukan dengan analisis korelasi ganda. Hasil analisis untuk mengetahui korelasi hubungan signifikan antara Pemahaman tentang Globalisasi dan Sikap Cinta Tanah Air dengan Pelestarian Budaya Bangsa, maka diperoleh $r_{\text {hitung }}=0,6117$. Hasil tersebut kemudian dikonsultasikan dengan $r_{\text {tabel }}=0,1459(\alpha=0,05$ dan $\mathrm{N}=181)$. Hasil konsultasi tersebut menunjukan $r_{\text {hitung }}=0,6117 \geq 0,1459=r_{\text {tabel }}$.

Untuk signifikan pemahaman globalisasi $\left(\mathrm{X}_{1}\right)$ dan sikap cinta tanah air $\left(\mathrm{X}_{2}\right)$ dengan pelestarian budaya bangsa (Y) menggunakan Uji-F. Adapaun hasil Uji-F sebagai berikut.

Tabel 4. Uji-F

\begin{tabular}{cccc}
\hline Variabel & $t_{\text {hitung }}$ & $t_{\text {tabel }}$ & Ket \\
\hline $\begin{array}{l}\text { Pemahaman globalisasi }\left(\mathrm{X}_{1}\right) \text { dan Sikap cinta tanah } \\
\text { air }\left(\mathrm{X}_{2}\right) \text { terhadap pelestarian budaya bangsa (Y) }\end{array}$ & 30,429 & 2,045 & Signifikan \\
\hline
\end{tabular}

Berdasarkan tabel tersebut dapat diketahui bahwa $t_{\text {hitung }}$ lebih dari $t_{\text {tabel }}$, maka antar variabel memiliki hubungan yang signifikan.

Tabel 5. Uji Koefisien Determinasi

\begin{tabular}{lrrrr}
\hline Model & $R$ & $R$ Square & Adjusted $R$ Square & Std. Error of the Estimate \\
\hline 1 & $.612^{\mathrm{a}}$ & .374 & .367 & 10.17472 \\
\hline \multicolumn{2}{r}{ a. Predictors: (Constant), Sikap Cinta Tanah Air, Pemahaman Globalisasi }
\end{tabular}

Berdasarkan Tabel 5, besar angka koefisien determinasi ( $R$-Square) adalah 0,374 atau sama dengan $37,4 \%$. Angka tersebut mengandung arti bahwa variabel pemahaman globalisasi (X1) dan variabel sikap cinta tanah air (X2) secara simultan berpengaruh terhadap variabel pelestaraian budaya bangsa (Y) sebesar 387,4\%. Sedangkan sisanya $(100 \%-37,4 \%=62,6 \%)$ dipengaruhi oleh variabel lain di luar persamaan regresi ini atau variabel yang tidak diteliti.

\section{KESIMPULAN}

Hasil penelitian dapat disimpulkan bahwa terdapat hubungan signifikan antara Pemahaman Globalisasi dan Sikap Cinta Tanah Air dengan Pelestarian Budaya Bangsa dilakukan dengan analisis korelasi ganda. Hasil analisis untuk mengetahui korelasi hubungan signifikan antara Pemahaman Globalisasi dan Sikap Cinta Tanah Air dengan Pelestarian Budaya Bangsa, maka diperoleh $r_{\text {hitung }}$ sebesar 0,6117. Hasil tersebut kemudian dikonsultasikan dengan $r_{\text {tabel }}=0,1459(\alpha=0,05$ dan $\mathrm{N}=181)$. Hasil konsultasi tersebut menunjukan bahwa $r_{\text {hitung }}=0,6117 \geq 0,1459=r_{\text {tabel, }}$. Hal ini menunjukan bahwa ada hubungan signifikan antara Pemahaman Globalisasi dan Sikap Cinta Tanah Air dengan Pelestaraian Budaya Bangsa dari 181 siswa SMK Arahman Depok. Dari perhitungan koefisien determinan (KD) diketahui bahwa hubungan Pemahaman Globalisasi dan Sikap Cinta Tanah Air adalah sebesar $37,4 \%$ sedangkan $62,6 \%$ ditentukan oleh faktor lain. 


\section{REFERENSI}

Arjoni, A., \& Handayani, T. (2017). Peran Madrasah dalam Menangkal Dampak Negatif Globalisasi terhadap Perilaku Remaja. JIP (Jurnal Ilmiah PGMI), 3(1), $1-14$.

Iriansyah, H. S. (2020). Krisis Asia, Kapitalisme dan Negara Kesejahteraan (Tinjauan Analisis Kapitalisme Korea Selatan). Jurnal Ilmu Pendidikan (JIP) STKIP Kusuma Negara, 12(1), 53-60.

Kartini, K. (2017). Memahami Ketimpangan Informasi di Era Globalisasi. AtTanzir: Jurnal Ilmiah Prodi Komunikasi Penyiaran Islam, 59-74.

Pudjiastuti, S. R. (2018). Implementation of The Mind Mapping Model With Scattergories Game in Improving Creativity and Learning Outcomes in National Education Materials. JHSS (Journal Of Humanities and Social Studies), 2(2), 22-24.

Pudjiastuti, S. R. (2019). Metode Penelitian Pendidikan. Yogyakarta: Media Akademi.

Pudjiastuti, S. R. (2020). Meningkatkan Pemahaman Materi Globalisasi dan Sikap Sosial Siswa melalui Model Pembelajaran Kooperatif Group Investigation di Kelas IV Madrasah Ibtidaiyah Nurul Huda Cimanggis Depok. Jurnal Pendidikan dan Pengajaran Guru Sekolah Dasar (JPPGuseda), 3(1), 1-5.

Sugiyono. (2008). Metode Penelitian Pendidikan: Pendekatan Kuantitatif, Kualitatif dan $R \& D$. Bandung: Alfabeta.

Suyadi. (2013). Strategi Pembelajaran Pendidikan Karakter. Bandung: Remaja Rosdakarya.

Suwarna, S., \& Jatirahayu, S. D. (2013). Pembelajaran Karakter yang Menyenangkan (Refleksi Sebuah Pengalaman). Jurnal Pendidikan Karakter, 3(3), 274-287.

Riwanto, R. (2016). Globalisasi Perubahan Sosial Budaya Dan Krisis Multidimensi Di Indonesia. Social Studies, 4(2), 17-29.

Rostini, T. (2018). Meningkatkan Pemahaman Siswa tentang Konsep Globalisasi dan Sikap Cinta Tanah Air melalui Metode Diskusi pada Mata Pelajaran PKn Kelas VI di SDN Nagrak 02 Kecamatan Sukaraja Kabupaten Bogor. Modeling: Jurnal Program Studi PGMI, 5(2), 171-184.

Rusli, W. (2013). Sistem Pendidikan Islam Menurut Hos Cokroaminoto (Konsep Muslim Nasional Onderwijs, Historis Dan Globalisasi). Jurnal Kependidikan, 1(1), 45-63. 